\section{North Atlantic Paleoceanography: The Last Five Million Years}

\section{PAGES 129, 133}

In the North Atlantic, cold, relatively salty water sinks in the icy Labrador and Greenland seas, forming North Atlantic Deep Water (NADW). This circulates through the global ocean, driving ocean overturning and global heat transport and, thus, impacting global climate. As one of the most climatically sensitive regions on Earth, the North Atlantic has experienced abrupt changes to its oceanatmosphere-cryosphere system, triggered by fluctuations in meltwater delivery to source areas of NADW formation.

For about the past 100 thousand years, these abrupt jumps in climate state have manifested as 'Dansgaard/Oeschger' (D/O) oscillations (millennial-scale warm-cold oscillations) and 'Heinrich' events in ice and marine sediment cores, respectively [e.g., These Heinrich events are characterized as huge input of ice-rafted debris (IRD) and meltwater pulses, documenting episodes of sudden instability and collapse of the current Greenland ice sheets and the Laurentide ice sheet, the latter of which covered northern North America several times during the Pleistocene Epoch.

Understanding the mechanisms and causes of the abrupt climate change is one of the major challenges in global climate change tion of the long-term evolution of millennialscale variability in surface temperature, ice sheet stability as a source for meltwater discharge, and thermohaline circulation can provide clues to the mechanisms responsible for abrupt climate change, which are still poorly understood in detail.

To shed more light on these topics, the North Atlantic Ocean was visited by scientific drilling ship JOIDES Resolution during Integrated Ocean Drilling Program (IODP) Expedition 306 in March-April 2005. The main goal of Expedition 306 - as was the main goal of Expedition 303-was to generate a continuous high-resolution chronology spanning the last $\sim 5$ million years (late Neogene-Quaternary), using North Atlantic climate proxies collected from layers of ocean sediments.

Using a range of stratigraphic tools, including stable isotopes and relative (geomagnetic) paleointensity [e.g., Channell et al.,

By R. Stein, T. Kanamatsu, C.Alvarez-Zarikian, S.M. HigGins, J.E.T. Channell, E. Aboud, M. OHNo, G.D. ACTON, K. АKIMOTO, I. BAILEY, K.R. BJøRKLUND, H. EVANS, S.H.H. NIELSEN, N. FANG, P.FERRETTI, J. GRuetzNER,Y.J.B. GuYOdo, K. HAGino, R. HARRIS, K. HATAKEDA, J. HeFter, S.A. JudGe, D.K. KuLHANEK, FNanayama, H. Rashid, F J. Sierro SancheZ, A.VOELKER, AND Q. ZHAI Dansgaard et al., 1993; Bond and Lotti, 1995]. research today. In this context, the determina-
2004; Shipboard Scientific Party, 2005; Expedition Scientists, 2005], these records will be correlated at scales much smaller than the Milankovitch cycles of eccentricity $(100,000$ years), obliquity (41,000 years), and precession (23,000 years), which are known to externally govern climate changes. For this specific research program, nine holes were drilled to a depth of several hundred meters below the seafloor at three sites in the central North Atlantic between $40^{\circ}$ and $56^{\circ} \mathrm{N}$ in water depth between 2800 and 3400 meters, using the advanced piston coring (APC) system (see Figure 1: Sites U1312, U1313, and U1314).

As a second important objective of Expedition 306, a borehole observatory for measurements of sub-bottom temperatures for longterm reconstruction of bottom-water temperatures was installed successfully in a newly drilled 180-meter-deep hole close to the Ocean Drilling Program's Site 642 (see Figure 1: Site U1315). By analyzing sub-bottom temperature perturbations, a temperature record may be able to be reconstructed for the first time of bottom water during at least the past 100 years, i.e., going back in time far beyond the directly measured temperature records available up to now [Harris et al., 2006].

\section{Preliminary Results From Site U1313}

For this North Atlantic paleoceanographic study, more than 2.3 kilometers of sediment cores were recovered at the three sites. The preliminary shipboard data indicate that glacial/interglacial as well as (sub)millennial cycles of excellent quality are preserved in these sediments. As an example, some initial results from Site U1313 are presented here in more detail (Figures 2 and 3 ).

Site U1313 is a reoccupation of Deep Sea Drilling Project (DSDP) Site 607, located at the base of the upper western flank of the Mid-Atlantic Ridge in a water depth of 3426 meters, approximately 390 kilometers northwest of the Azores (Figure 1). Site 607 has been very important for generating a stable isotope stratigraphy for the last $\sim 3$ million years and for interpreting this stratigraphy in terms of ice sheet variability and changes in NADW circulation [e.g., Ruddiman et al., 1989]. DSDP Leg 94 drilling of this site, however, preceded the advent of the shipboard capability for construction of composite sections and pass-through magnetometers for continuous measurement of magnetic parameters. Furthermore, the present condition of existing DSDP cores collected in 1983 does not permit the high-resolution studies proposed here.

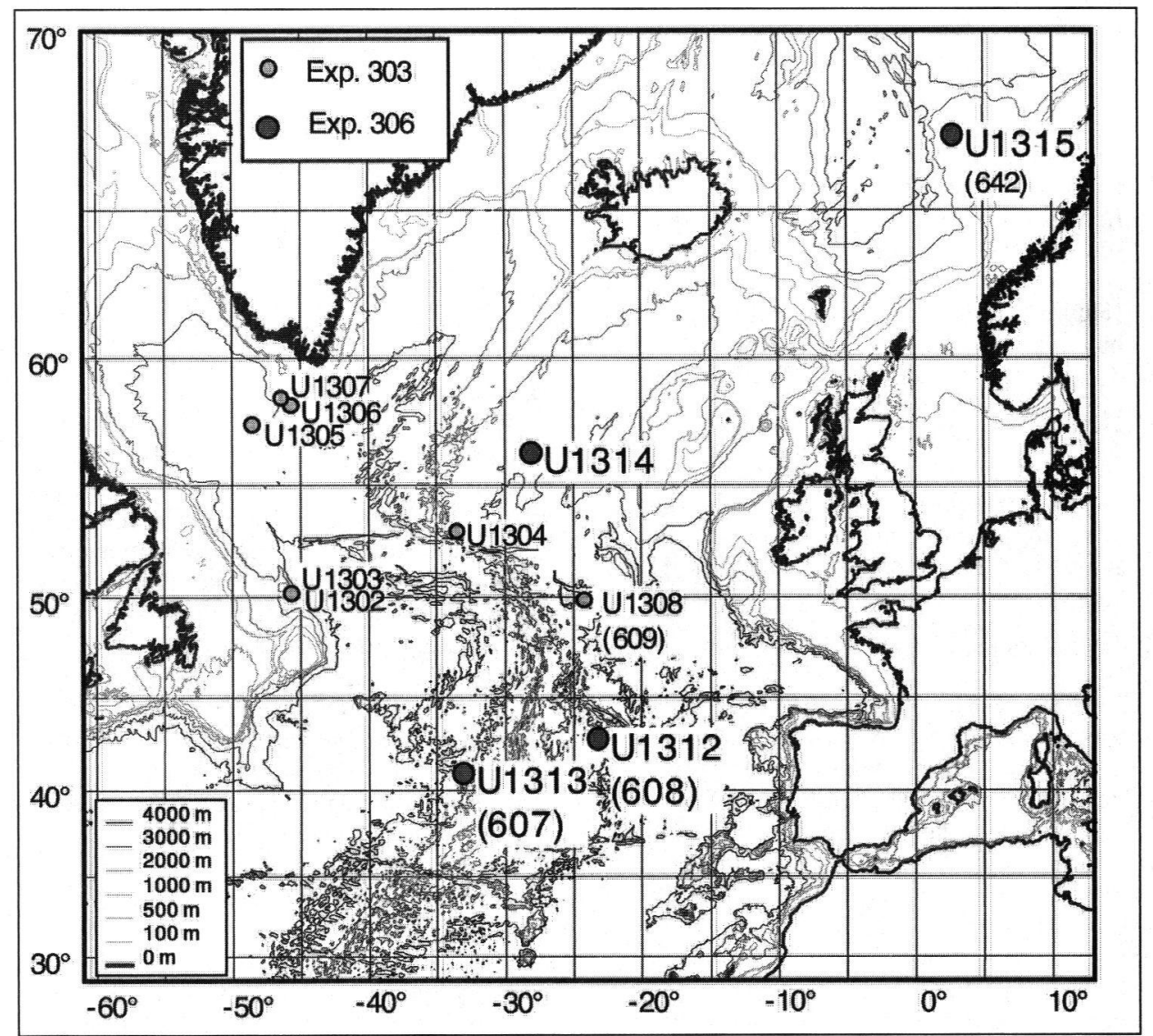

Fig. 1. Locations of sites drilled during expeditions 303 and 306. Cores that are reoccupied DSDP and ODP sites show the DSDP number (607,608, and 609) and ODP number (642) in parentheses. Original color image appears at the back of this volume. 
At Site U1313, four holes with a maximum penetration down to 308.6 meters below seafloor (mbsf) were drilled. The sedimentary succession of the last six million years (Holocene to latest Miocene) at Site U1313 consists primarily of nannofossil ooze with varying amounts of foraminifers and clayto gravel-sized terrigenous components. Biostratigraphy and magnetostratigraphy indicate uniform average sedimentation rates of about five centimeters per thousand years throughout the Pliocene to Holocene time interval [ 0 to 5 million years ago (Ma)], whereas in the late Messinian ( 5 to $6 \mathrm{Ma}$ ) sedimentation rates are increased to $\sim 13-14$ centimeters per thousand years.

The detrital components become much more important and variable in the upper Pliocene-Pleistocene interval of the sequence, as indicated by the magnetic susceptibility record [Expedition Scientists, 2005] as well as the records of carbonate, natural gamma radiation (NGR), and lightness $\left(\mathrm{L}^{*}\right)$ from color reflectance measurements (Figures 2 and 3), probably reflecting increased Northern Hemisphere ice sheet instability.

In particular, the $L^{*}$ record, controlled mainly by the variability of carbonate content [Expedition Scientists, 2005], mimics glacial/ interglacial variations in the global benthic oxygen isotope stack of Lisiecki and Raymo [2005] in detail. The peaks and troughs of the oxygen record through time, labeled as marine isotope stages (MIS), show that when compared to the $\mathrm{L}^{*}$ record, MIS 11 was the most prominent Pleistocene interglacial interval (Figure 2). A preliminary age model was constructed by matching sharp $L^{*}$ variations with glacial and interglacial terminations (Figure 2).

First results from biomarker analysis already performed onboard the JOIDES Resolution indicate that alkenone-derived sea surface temperatures (SST) show a variability from $\sim 13^{\circ}$ to $19^{\circ} \mathrm{C}$ in the Pleistocene (Figure 2), although interglacial maxima have probably not yet been sampled. A few data points from the upper Pliocene interval (1.9 to $3.2 \mathrm{Ma}$ ) display SST values of about $17^{\circ}-22^{\circ} \mathrm{C}$. The Pleistocene SST variability of about $6^{\circ} \mathrm{C}$ agrees with the last glacial maximum (about 20,000 years ago) to modern temperature difference estimated for the same area [Pflaumann et al., 2003].

\section{Implications of NGR Studies at Site U1313}

At Site U1313, in situ downhole logging was successfully carried out using a triple combo tool string. The records provided density, porosity, NGR, resistivity, and photoelectric-effect data throughout the 300-meter sedimentary sequence. Corresponding core physical property measurements could be correlated with in situ downhole data. The consistency of downhole logging data with core data will allow mapping of the spliced core record to actual depth, resulting in more accurate sedimentation and mass accumulation rate calculations, as well as more detailed age-depth models.

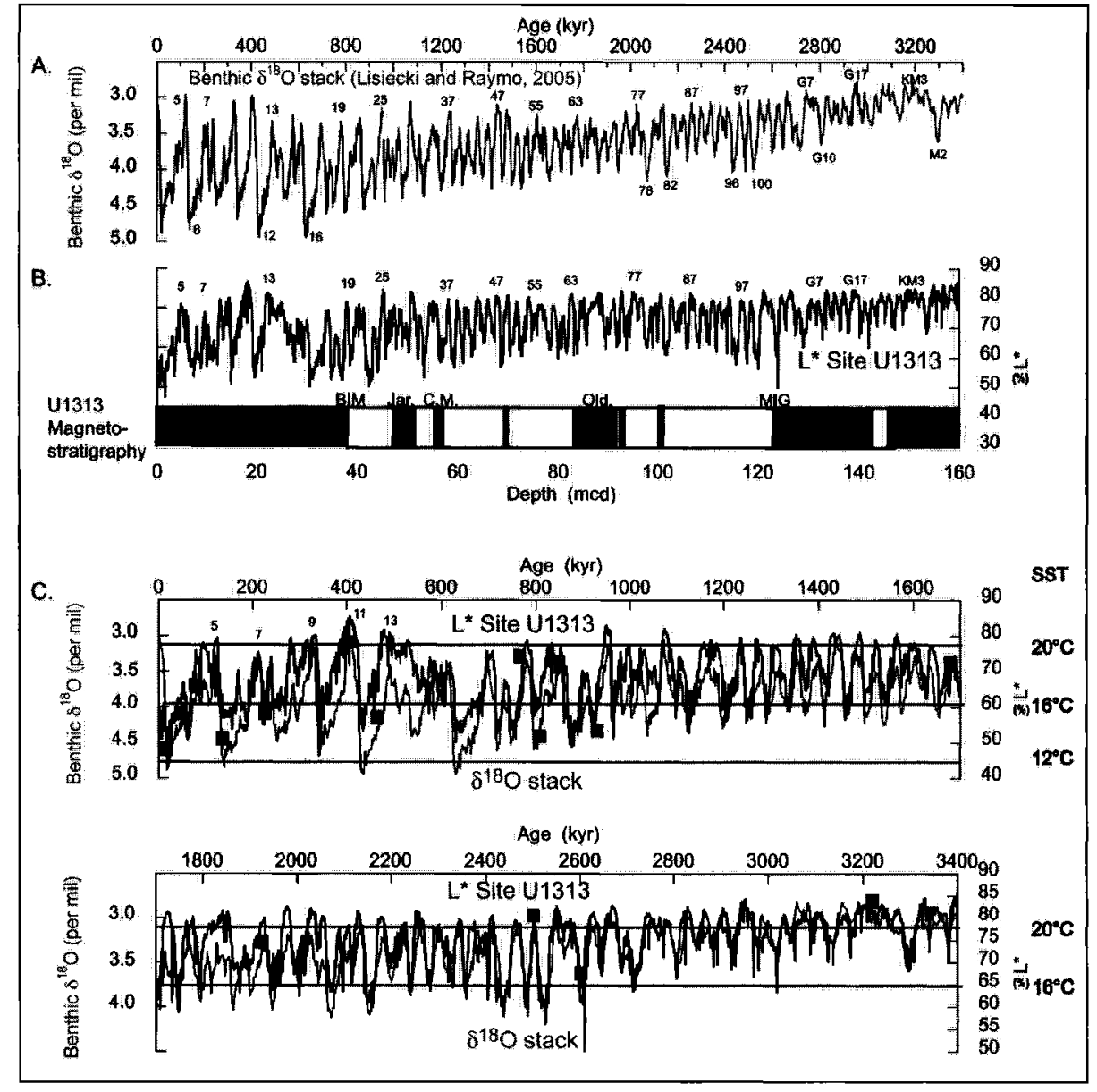

Fig. 2. Preliminary correlation between (a) the global benthic oxygen isotope stack of Lisiecki and Raymo [2005] and (b) the lightness $\left(L^{*}\right)$ measured in the upper 160 meters of Site U1312. In addition, the magnetostratigraphy of Site U1313 is shown. Numbers indicate marine oxygen isotope stages according to Lisiecki and Raymo [2005]. (c) By matching sharp L* variations with glacial and interglacial terminations, the Site U1313 depth scale was transferred into an age scale. In addition, sea surface temperatures (SST) as obtained from alkenone data of Site U1313 samples are shown as blue squares. Original color image appears at the back of this volume.

The NGR was measured with the Hostile Environment Gamma Ray Sonde in American Petroleum Institute gamma ray units (gAPI). In the upper 65 meters, the values were measured through the drill pipe and are attenuated by a factor of about four to five. For this part of the record, the original values were multiplied by a factor of five. Further information on the procedures and wireline tools used during Expedition 306 can be found at http://iodp.Ideo.columbia. edu/TOOLS_LABS/index.html

Of special note is the consistent linear correlation of downhole NGR (upper 225 mbsf) with the recent Lisiecki and Raymo [2005] benthic oxygen isotope stack of the past 5.3 million years (Figure 3 ). The NGR value is mainly driven by the radiogenic thorium concentrations derived from clay content. By interpreting the NGR signal as a record for detrital clay input, the following still preliminary statements can be made:

- Very low and almost constant NGR values, paralleled by very high carbonate contents of more than 90 percent, are typical for the lower part of the record, indicating low detrital input prior to about $3.3 \mathrm{Ma}$.
- At about 140 mbsf, correlating with MIS $\mathrm{M} 2$ at 3.3 Ma (see Figure 2), a first increase in NGR values suggests slightly increased detrital input.

- At 115 mbsf (near 2.75 Ma, MIS G6-G10, and contemporaneous with the onset of major Northern Hemisphere glaciation), NGR values significantly increased, carbonate contents decreased and gravel-sized dropstones frequently occurred (Figure 3), indicating extended glaciation. Distinct NGR maxima occurred between 106 and $86 \mathrm{mbsf}$, correlating with the prominent glacial stages $100,98,96,82$, and 78 (see Figure 2).

- Between 86 and 52 mbsf (between about 2.05 and $1.25 \mathrm{Ma}$ ), maximum NGR values are lower than in the previous interval (except one peak at about 60 mbsf or $1.4 \mathrm{Ma}$ ), suggesting reduced detrital input.

- The upper 52 meters (the past 1.25 million years) display high-amplitude variations in NGR (detrital input) related to a pronounced glacial/interglacial instability of major Northern Hemisphere ice sheets. A shift toward higher amplitude and more glacial conditions occurred between 0.95 and $0.65 \mathrm{Ma}$, during the Mid-Pleistocene climate 
transition (Figure 3) [Ruddiman et al., 1989; Mudelsee and Schulz, 1997].

From the multidisciplinary studies to be performed on these new IODP cores (together with the sites from IODP Expedition 303) during the coming years, new milestones in the understanding of mechanisms and causes of abrupt climate change, one of the major challenges in global climate change research today, are expected to be reached.

\section{Acknowledgments}

This success of Expedition 306 was the result of excellent cooperation between the IODP staff, the Transocean employees, and the Shipboard Science Party.

\section{References}

Bond, G. C., and R. Lotti (1995), Iceberg discharges into the North Atlantic on millennial time scales during the last glaciation, Science, 267, 1005-1010.

Channell, J.E.T., et al. (2004), North Atlantic climate, Expeds. 303/306 Sci. Prosp., Integrated Ocean Drill. Prog.,Washington, D. C. (Available at http://iodp.tamu.edu/publications/SP/303306SP/ 303306SP.PDF)

Dansgaard,W., et al. (1993), Evidence for general instability of past climate from a 250 kyr ice core record, Nature, 364, 218-220.

Expeditions Scientists (2005), North Atlantic climate 2, Prel. Rep. 306, doi:10.2204/iodp.pr.306.2005, Integrated Ocean Drill.Prog., Washington, D. C.

Harris, R. N., et al. (2006), Borehole Observatory Installations on IODP Expedition 306 Reconstruct Bottom-Water Temperature Changes in the Norwegian Sea, Scientific Drilling, 2, 28-31.

Lisiecki, L. E., and M. E. Raymo (2005), A PliocenePleistocene stack of 57 globally distributed benthic $\delta^{18} \mathrm{O}$ records, Paleoceanography, 20, PA1003, doi:10.1029/2004PA001071.

Mudelsee, M., and M.Schulz (1997), The Mid-Pleistocene climate transition: Onset of 100 ka cycle lags ice-volume build-up by $280 \mathrm{ka}$,Earth Planet. Sci. Lett., 151, 117-123.

Pflaumann U., et al. (2003), Glacial North Atlantic: Sea surface conditions reconstructed by GLAMAP 2000, Paleoceanography, 18(3), 1065, doi:10.1029/ 2002 PA000774.

Ruddiman, W. F., M. E. Raymo, D. G. Martinson, B. M. Clement, and J. Backman (1989), Pleistocene evolution: Northern Hemisphere ice sheets and North Atlantic Ocean, Paleoceanography, 4(4), 353-412.

Shipboard Scientific Party (2005), North Atlantic climate: Ice sheet-ocean atmosphere interactions on millennial timescales during the late NeogeneQuaternary using a paleointensity-assisted chronology for the North Atlantic, Exped. 303 Prelim. Rep., Integrated Ocean Drill.Prog.,Washington, D. C. (Available at http://iodp.tamu.edu/ publications/PR/303PR/303PR.PDF)

\section{Author Information}

Ruediger Stein, Alfred Wegener Institute for Polar and Marine Research, Bremerhaven, Germany,

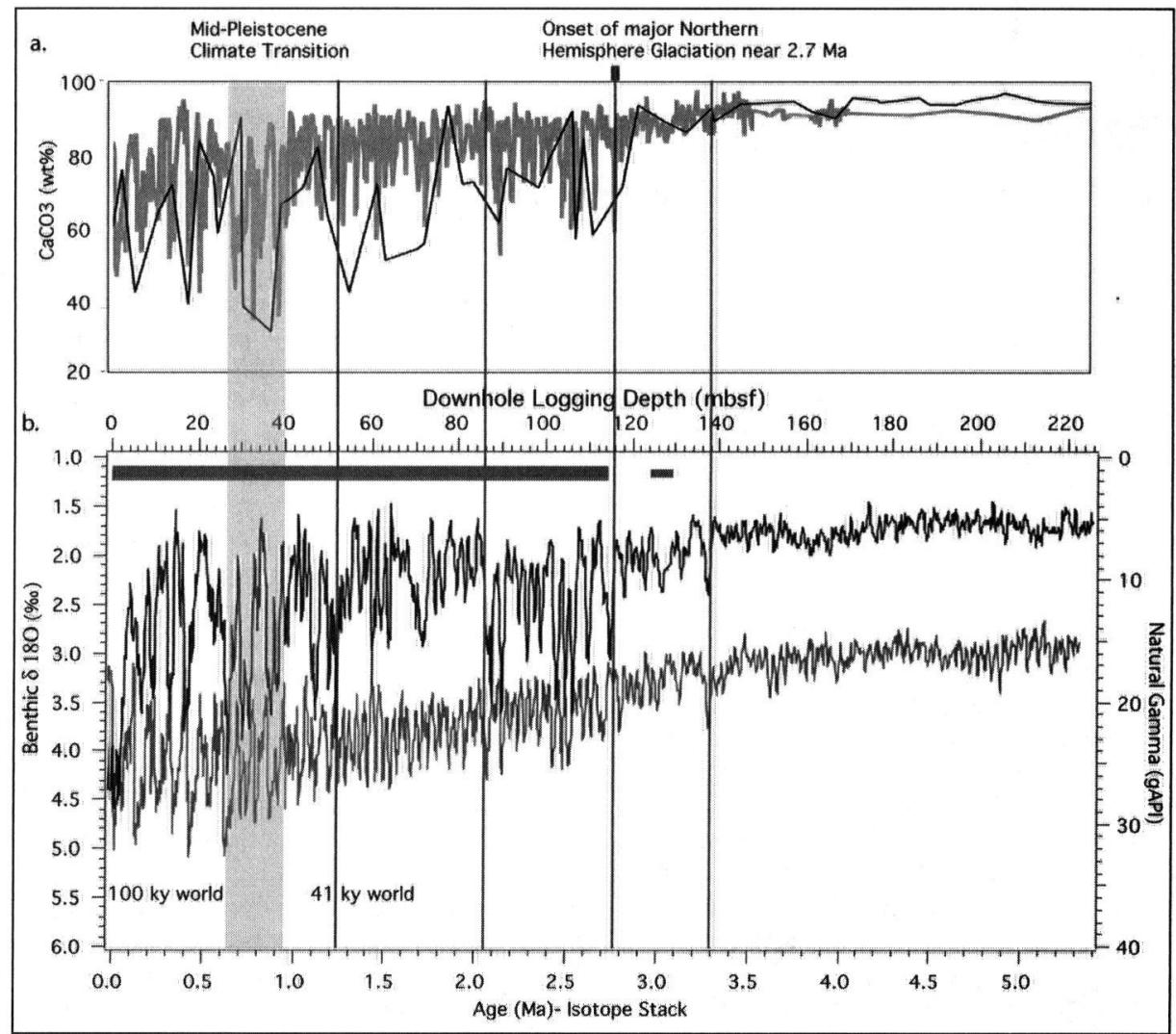

Fig. 3. (a) A preliminary low-resolution carbonate record of hole U1313A (black) and a high-resolution carbonate record of DSDP Site 607 (orange) [Ruddiman et al., 1989]. (b) Linear correlation of logging natural gamma radiation (using HSGR) (black) from hole U1313B and benthic oxygen isotope stack (red) over the past 5.3 million years [Lisiecki and Raymo, 2005].The correlation has only two tie points at 0 and 5.2 Ma with no stretching or squeezing of logging data depths.Vertical blue lines indicate major changes in the NGR record. The blue-shaded interval between 0.6 and 0.9 Ma marks the Mid-Pleistocene climate shift, where obliquity periodicity transitions from a dominant 41,000-year cycle to a dominant 100,000-year cycle [e.g., Mudelsee and Schulz, 1997].The brown bar marks the occurrence of gravel-sized dropstones. Original color image appears at the back of this volume.

E-mail: rstein@awi-bremerhaven.de; Toshiya

Kanamatsu, Institute for Research on Earth Evolution, Kanagawa, Japan; Carlos Alvarez-Zarikian, Texas A\&M University, College Station; Sean M. Higgins, Lamont-Doherty Earth Observatory of Columbia University, Palisades, N.Y.; Jim E.T. Channell, Department of Geological Sciences, University of Florida, Gainesville; Essam Aboud and Masao Ohno, Kyushu University, Fukuoka, Japan; Gary D. Acton, University of California, Davis; Kazumi Akimoto, Kumamoto University, Japan; Ian Bailey, University College, London, U.K.; Kjell R. Bjørklund, University of Oslo, Norway; Helen Evans and Simon H.H. Nielsen, University of Florida, Gainesville; Nianqiao Fang, China University of Geosciences, Beijing; Patrizia Ferretti, University of Cambridge, $U$. K.; Jens Gruetzner, University of Bremen, Germany; Yohan J.B. Guyodo, Laboratoire des Sciences du Climat et de I'Environnement, Gif-sur-Yvette, France; Kentaro Hagino, Hokkaido University, Sap- poro, Japan; Robert Harris, Oregon State University, Corvallis; Kentaro Hatakeda,Tohoku University, Sendai, Japan; Jens Hefter, Alfred Wegener Institute for Polar and Marine Research, Bremerhaven, Germany; Shelley A. Judge, Ohio State University, Columbus; Denise K. Kulhanek, Florida State University, Tallahassee; Futoshi Nanayama, Geological Survey of Japan, Ibaraki; Harunur Rashid, University of South Florida, St. Petersburg; Francisco J. Sierro Sanchez, Universidad de Salamanca, Spain; Antje Voelker, Instituto Nacional de Engenharia Tecnologia e Inovacao, Alfragide, Portugal; and Qiumin Zhai, University of Tokyo, Japan. 
Eos, Vol. 87, No. 13, 28 March 2006

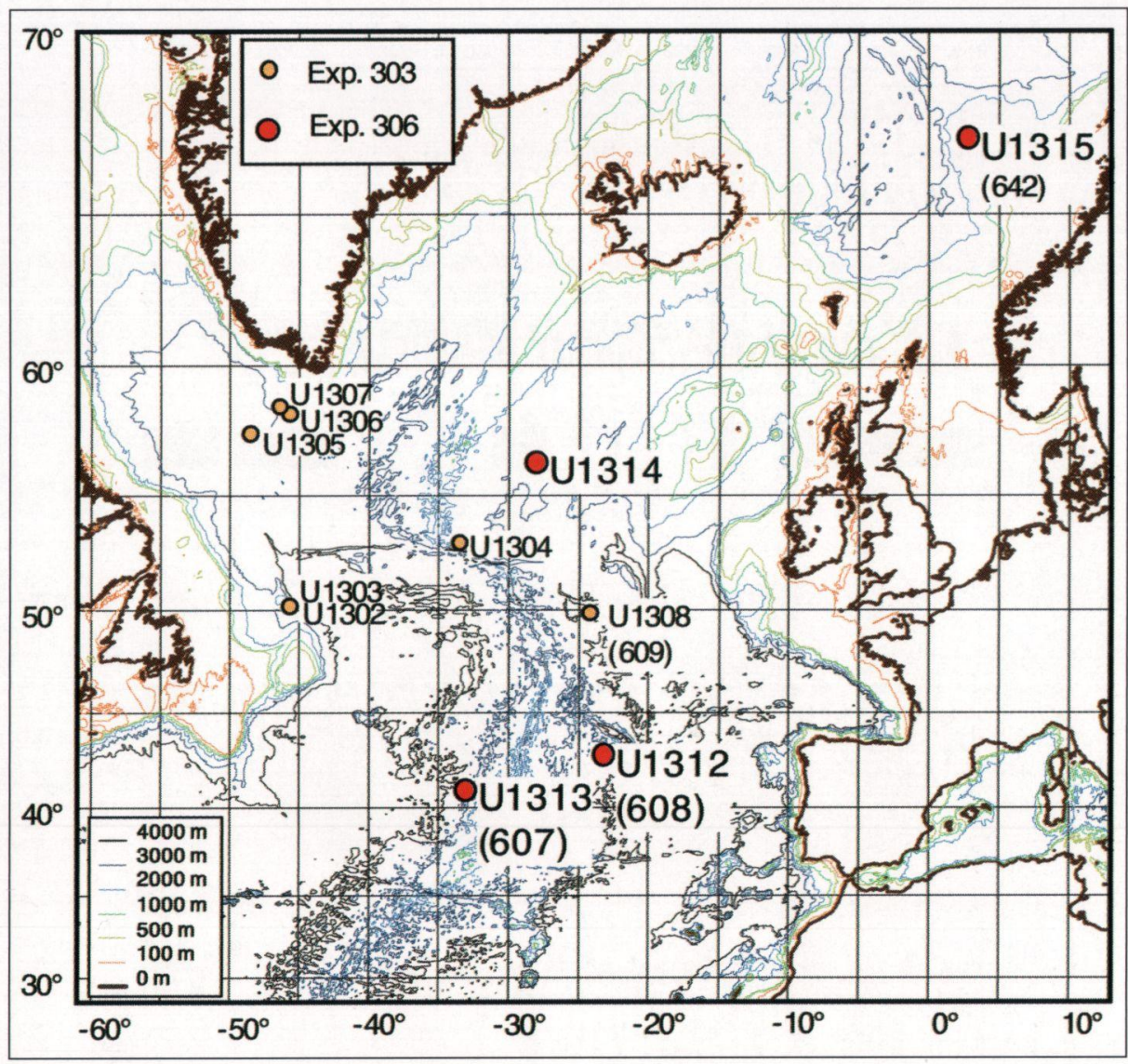

Fig. 1. Locations of sites drilled during expeditions 303 and 306. Cores that are reoccupied DSDP and ODP sites show the DSDP number $(607,608$, and 609) and ODP number (642) in parentheses. 
Eos, Vol. 87, No. 13, 28 March 2006

Page 133

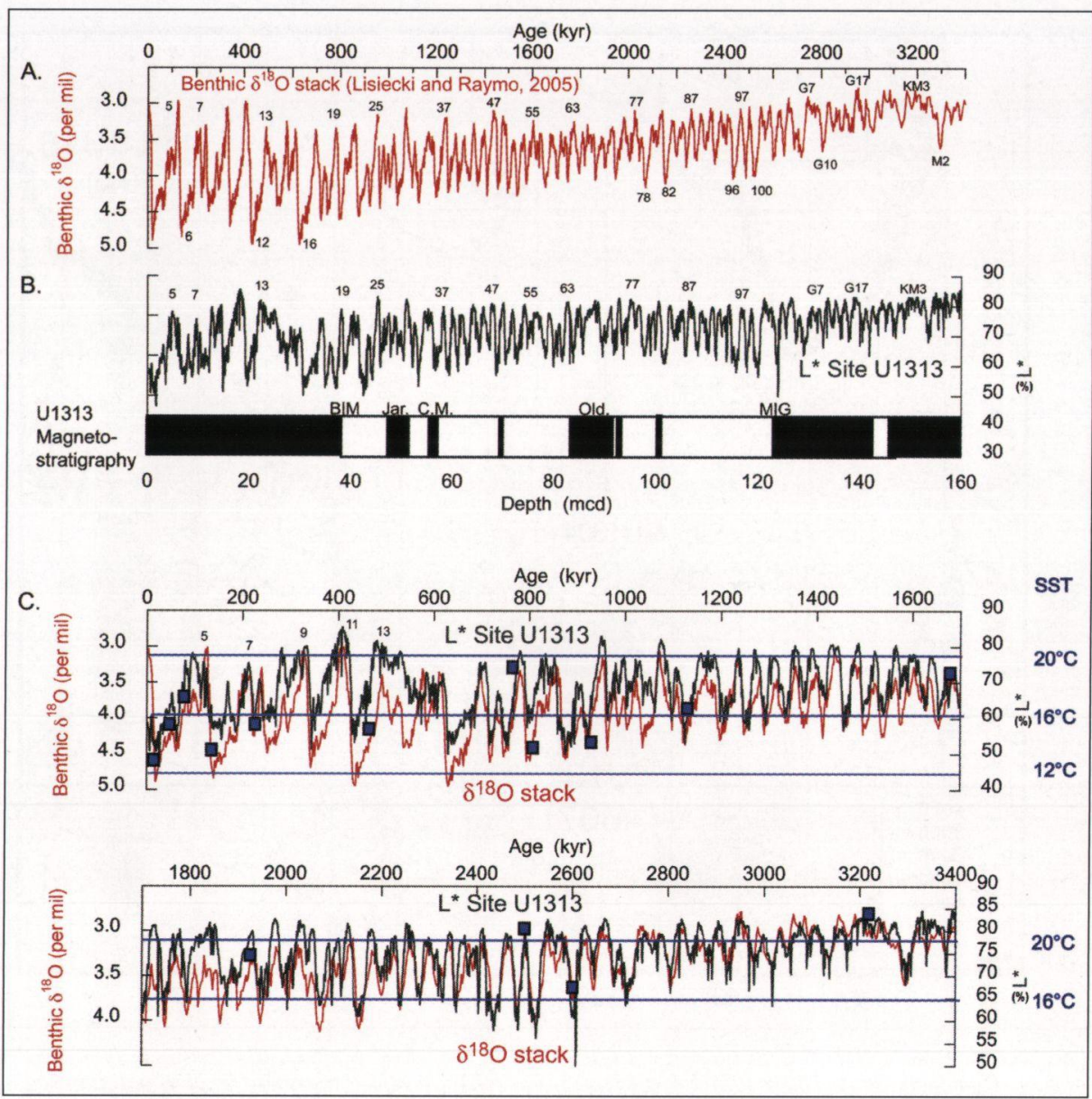

Fig. 2. Preliminary correlation between (a) the global benthic oxygen isotope stack of Lisiecki and Raymo [2005] and (b) the lightness $\left(L^{*}\right)$ measured in the upper 160 meters of Site U1312. In addition, the magnetostratigraphy of Site U1313 is shown. Numbers indicate marine oxygen isotope stages according to Lisiecki and Raymo [2005]. (c) By matching sharp L* variations with glacial and interglacial terminations, the Site U1313 depth scale was transferred into an age scale. In addition, sea surface temperatures (SST) as obtained from alkenone data of Site U1313 samples are shown as blue squares. 
Eos, Vol. 87, No. 13, 28 March 2006

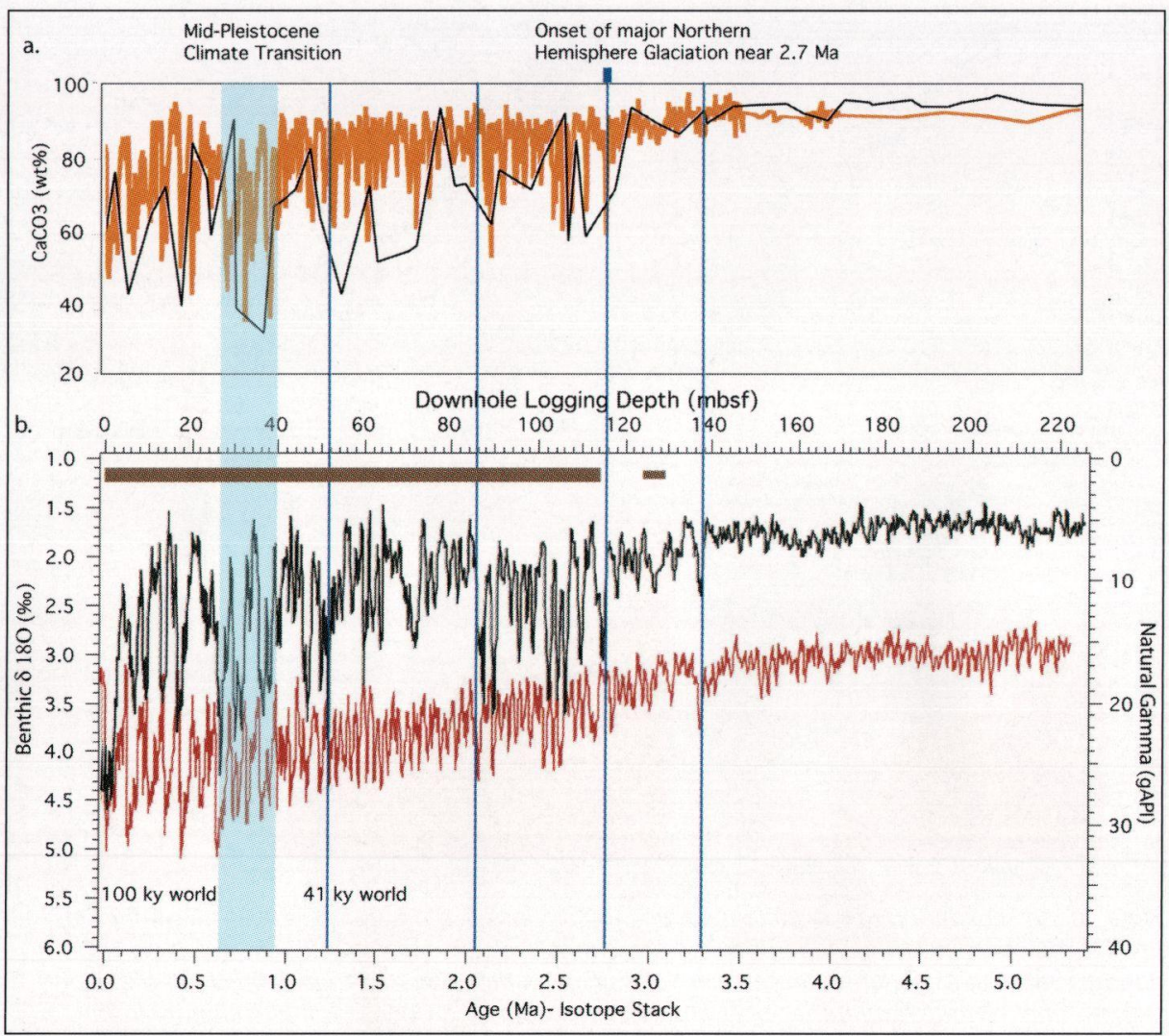

Fig. 3. (a) A preliminary low-resolution carbonate record of hole U1313A (black) and a high-resolution carbonate record of DSDP Site 607 (orange) [Ruddiman et al., 1989]. (b) Linear correlation of logging natural gamma radiation (using HSGR) (black) from hole U1313B and benthic oxygen isotope stack (red) over the past 5.3 million years [Lisiecki and Raymo, 2005]. The correlation has only two tie points at 0 and 5.2 Ma with no stretching or squeezing of logging data depths. Vertical blue lines indicate major changes in the NGR record. The blue-shaded interval between 0.6 and 0.9 Ma marks the Mid-Pleistocene climate shift, where obliquity periodicity transitions from a dominant 41,000-year cycle to a dominant 100,000-year cycle [e.g., Mudelsee and Schulz, 1997].The brown bar marks the occurrence of gravel-sized dropstones. 